\title{
Thymidine Kinase of Bacteria: Activity of the Enzyme in Actinomycetes and Related Organisms
}

\author{
By HAJIME SAITO* AND HARUAKI TOMIOKA \\ Department of Microbiology and Immunology, Shimane Medical University, Izumo 693, Japan
}

(Received 11 October 1983; revised 14 March 1984)

\begin{abstract}
Various micro-organisms were studied for their thymidine kinase (adenosine 5'-triphosphate :thymidine 5'-phosphotransferase, EC 2.7.1.21) (TK) activity. The sonicated cell extract of Escherichia coli K12 had a TK activity of 35-66 pmol thymidine monophosphate formed $\min ^{-1}$ (mg protein $)^{-1}$. The cell extracts of Salmonella typhimurium and Klebsiella pneumoniae showed a markedly higher (5- to 11-fold) TK activity. Somewhat lower but significant TK activity was detected in the cell extracts of Staphylococcus aureus, Streptococcus pyogenes, Bacillus subtilis and Proteus mirabilis. In contrast, weak TK activity, if any, was detected in the cell extracts of Pseudomonas aeruginosa. This was also the case with respect to the cell extracts of various actinomycetes (such as Nocardia and Streptomyces) and related organisms (such as Corynebacterium, Mycobacterium and Rhodococcus).
\end{abstract}

\section{INTRODUCTION}

Thymidine kinase (TK), one of the key enzymes in the pyrimidine salvage pathway, catalyses the phosphorylation of thymidine (TdR) to thymidine 5'-monophosphate (TMP) (Okazaki \& Kornberg, 1964a; Ellims \& Van Der Weyden, 1981). The physiological importance of TK is indicated by its high activity in cells which engage in active DNA synthesis (Hotta \& Stern, 1963 ) and by the evolution of an intricate feedback system to regulate it (Okazaki \& Kornberg, $1964 b$ ). The physiological function of TK is also evident because TMP is able to correct its deficiency in cells which lack thymidylate synthetase or in cells in which the synthetase is inhibited for some reason. With respect to the TK of micro-organisms, however, only a few studies have been reported: TK from Escherichia coli (Okazaki \& Kornberg, 1964a, b), Bacillus megaterium (Wachsman \& Morgan, 1971), Mycoplasma hominis (Stock \& Gentry, 1971), and Dictyostelium discoideum (Michrina \& Deering, 1980). The precise pattern of TK distribution among various micro-organisms has not been documented. Grivell \& Jackson (1968) reported the lack of TK in some ascomycetes such as Neurospora crassa, Aspergillus nidulans, Saccharomyces cerevisiae and Euglena gracilis, and Mizuno (1969) found that Pseudomonas schuylkilliensis also lacks TK.

In a preliminary experiment, we found that rapidly growing mycobacteria did not efficiently incorporate $\left[{ }^{3} \mathrm{H}\right] \mathrm{TdR}$ into their DNA. This was not overcome by 5 -fluorodeoxyuridine (FUdR), which is converted to 5-fluorodeoxyuridylate in vivo and inhibits thymidylate synthetase, a key enzyme of de novo deoxythymidine triphosphate (TTP) synthesis (Mathews \& Cohen, 1963). Deoxyadenosine (AdR) did not lead to an uptake of $\left[{ }^{3} \mathrm{H}\right] \mathrm{TdR}$ to DNA by these mycobacteria. Because the de novo pathway of TTP synthesis is assumed to suppress the TK activity in the salvage pathway and because AdR inhibits TdR degradation by depressing TdR phosphorylase activity (Yagil \& Rosner, 1970), the rapidly growing mycobacteria seemed to lack TK activity. This finding led us to study the precise distribution pattern of TK in various micro-organisms, especially in mycobacteria and related organisms. It is of interest to know whether or not these microbes can produce intrinsic TK, which determines their ability to use a scavenger pathway to supply TMP (and finally TTP) for DNA synthesis.

\footnotetext{
Abbreviations: Adr, deoxyadenosine; FUdR, 5-fluorodeoxyuridine; TdR, thymidine; TK, thymidine kinase; TMP, thymidine monophosphate; TTP, deoxythymidine triphosphate.
} 


\section{METHODS}

Organisms. The following organisms were used: Escherichia coli, Salmonella typhimurium, Klebsiella pneumoniae, Proteus mirabilis, Pseudomonas aeruginosa, Staphylococcus aureus, Streptococcus pyogenes, Bacillus subtilis, Corynebacterium cystitidis, $C$. pilosum, C. renale, Streptomyces roseoviridis, $S$. lavendulae, $S$. platensis, $S$. violascens, Nocardia asteroides, $N$. brasiliensis, Rhodococcus aurantiacus, Mycobacterium tuberculosis, $M$. bovis, $M$. kansasii, $M$. marinum, M. gordonae, $M$. scrofulaceum, $M$. intracellulare, $M$. nonchromogenicum, M. terrae, $M$. gastri, $M$. fortuitum, $M$. chelonae (chelonei) subsp. abscessus, $M$. smegmatis, $M$. phlei, $M$. chitae, $M$. parafortuitum and $M$. diernhoferi. Strain numbers are given in the relevant tables.

Chemicals. The following radioactive chemicals were purchased from New England Nuclear: $\left[{ }^{3} \mathrm{H}\right] l$ leucine, $\left[{ }^{3} \mathrm{H}\right]-$ uridine, $\left[{ }^{3} \mathrm{H}\right]$ adenine and $\left[{ }^{3} \mathrm{H}\right]$ thymidine. Deoxyadenosine and adenosine $\mathrm{S}^{\prime}$-triphosphate were obtained from P-L Biochemicals, Milwaukee, USA and Oriental Yeast Co., Osaka, Japan, respectively. Other special agents were purchased from Wako Pure Chemical Inc., Osaka, Japan.

Assay for leucine, uridine, adenine and TdR incorporation. Some rapidly growing mycobacteria and E. coli $\mathrm{K} 12$ were cultured in heart infusion broth (Eiken Chemicals Co., Tokyo, Japan) and in the same broth containing $4 \%$ glycerol with $0 \cdot 1 \%(\mathrm{v} / \mathrm{v})$ Tween 80 at $37^{\circ} \mathrm{C}$ for $2 \mathrm{~d}$ with shaking. The organisms were harvested and then suspended in the corresponding fresh medium at an optical density at $540 \mathrm{~nm}$ of 1 or 2 . After addition of $\left[{ }^{3} \mathrm{H}\right]$ leucine $\left(5 \mathrm{Ci} \mathrm{mol}^{-1}, 2 \mu \mathrm{Ci} \mathrm{ml}{ }^{-1} ; 1 \mathrm{Ci}=37 \mathrm{GBq}\right),\left[{ }^{3} \mathrm{H}\right]$ uridine $\left(5 \mathrm{Ci} \mathrm{mol}^{-1}, 2 \mu \mathrm{Ci} \mathrm{ml}^{-1}\right),\left[{ }^{3} \mathrm{H}\right]$ adenine $\left(1 \mathrm{Ci} \mathrm{mol}^{-1}\right.$, $\left.2 \mu \mathrm{Ci} \mathrm{m}^{-1}\right)$, or $\left[{ }^{3} \mathrm{H}\right] \mathrm{TdR}\left(5 \mathrm{Ci} \mathrm{mol}^{-1}, 1\right.$ or $\left.2 \mu \mathrm{Ci} \mathrm{ml}^{-1}\right)$, cultivation was done at $37^{\circ} \mathrm{C}$ with reciprocal shaking at 90 cycles $\min ^{-1}$ for up to $4 \mathrm{~h}$. At various intervals, samples of culture (1 ml) were withdrawn, mixed with $1 \mathrm{ml}$ cold $20 \%(w / v)$ trichloroacetic acid (TCA), and the resultant precipitate was collected on a Whatman GFC glass fibre filter. After washing with 5\% TCA and then ethanol, the filter was dried and counted in a Packard Tri-Carb scintillation counter using toluene-based scintillation fluid. $\left[{ }^{3} \mathrm{H}\right]$ Adenine incorporation into DNA was assayed as follows. Samples of culture $(1 \mathrm{ml})$ were withdrawn, mixed with $2 \mathrm{ml} 1 \mathrm{M}-\mathrm{KOH}$, left to stand overnight at room temperature to hydrolyse RNA, and then mixed with $1.5 \mathrm{ml} 50 \%(w / v)$ TCA. The resultant precipitates were collected on glass fibre filters, washed with $5 \% \mathrm{TCA}$ and the ethanol and radioactivity were counted.

Preparation of cell extracts. Bacteria were cultured with shaking in heart infusion broth at $37^{\circ} \mathrm{C}$ for 1 to $2 \mathrm{~d}$, except for Streptococcus pyogenes which was cultured in heart infusion broth supplemented with $10 \%$ (v/v) foetal bovine serum. Other organisms such as actinomycetes and related organisms were cultured with shaking usually at $37^{\circ} \mathrm{C}$ using the following media: Corynebacterium, heart infusion broth (2 d) (Guirard \& Snell, 1981); Streptomyces, soluble starch/yeast extract medium $\left(30^{\circ} \mathrm{C}\right.$ for 5 to $7 \mathrm{~d}$ ) (Liu et al., 1977); Nocardia and Rhodococcus, heart infusion broth containing $4 \%$ (v/v) glycerol ( $2 \mathrm{~d}$ ) (Goodfellow, 1971); slowly growing mycobacteria, Dubos medium (Eiken; 10 to $12 \mathrm{~d}, M$. marinum was grown at $33^{\circ} \mathrm{C}$ ) (Wayne et al., 1964); rapidly growing mycobacteria, Dubos medium (Wayne et al., 1964) or heart infusion broth containing $4 \%(\mathrm{v} / \mathrm{v})$ glycerol and $0 \cdot 1 \%$ Tween $80(2 \mathrm{~d})$ (Takeya et al., 1978). Bacteria of each strain were harvested by centrifugation at $10000 \mathrm{~g}$ for $10 \mathrm{~min}$, washed once with $50 \mathrm{mM}$-Tris/ $\mathrm{HCl}$ buffer ( $\mathrm{pH} \mathrm{8.0)}$ containing $1 \mathrm{mM}$ each of dithiothreitol (DTT) and EDTA and suspended in the same buffer at a concentration of 0.05 to $0.25 \mathrm{~g}$ wet weight $\mathrm{ml}^{-1}$. The bacterial suspension was then sonicated using an ultrasonic disintegrator (Insonator, Model 200M; Kubota Shoji, Tokyo, Japan) at $200 \mathrm{~W}$ for $5 \mathrm{~min}$ followed by centrifugation at $20000 \mathrm{~g}$ for $30 \mathrm{~min}$. The supernatant was used as cell extract.

Assay for TK activity. Measurement of TK activity of cell extracts was done according to the method of Kizer \& Holman (1974) with modifications. Briefly, the reaction mixture $(0.2 \mathrm{ml})$ consisted of $62.5 \mathrm{mM}-\mathrm{Tris} / \mathrm{HCl}(\mathrm{pH} 8.0)$, $10 \mathrm{~mm}$-ATP, $10 \mathrm{mM}-\mathrm{MgCl}_{2}, 2.5 \mathrm{~mm}-\mathrm{NaF}, 1 \mathrm{~mm}-\mathrm{DTT}, 250 \mu \mathrm{g}$ bovine serum albumin $\mathrm{ml}^{-1}$ (as a stabilizer of TK) (Okazaki \& Kornberg, 1964a), $10 \mu \mathrm{M}-\left[{ }^{3} \mathrm{H}\right] \mathrm{TdR}\left(500 \mathrm{Ci} \mathrm{mol}^{-1}\right)$, and cell extract $(50$ or $100 \mu \mathrm{l})$. The reaction mixture was incubated with shaking at 100 cycles $\min ^{-1}$ at $37^{\circ} \mathrm{C}$ for up to $120 \mathrm{~min}$. After incubation, the mixture was boiled for $3 \mathrm{~min}$ and a $0.1 \mathrm{ml}$ sample was dispensed on a DEAE-cellulose paper $(2 \times 2.1 \mathrm{~cm}$; Tohyo Roshi Co., Tokyo, Japan). After drying at $90^{\circ} \mathrm{C}$ for $5 \mathrm{~min}$, the paper was rinsed in $1 \mathrm{~mm}$-ammonium formate and then ethanol, dried at $120^{\circ} \mathrm{C}$ and the radioactivity was counted in a liquid scintillation counter using toluene-based scintillation fluid. One unit of TK activity was defined as the amount of enzyme which generated 1 nmol TMP per $60 \mathrm{~min}$.

\section{RESULTS}

Indirect evidence for $T K$ deficiency in rapidly growing mycobacteria

Incorporation of $\mathrm{TdR}$ into high molecular weight cell components of $M$. diernhoferi ATCC 19340 was markedly lower than incorporation of leucine and uridine (Fig. $1 a$ ). Since the incorporation of leucine and uridine were specifically inhibited by streptomycin and by rifampicin, respectively, most of the $\left[{ }^{3} \mathrm{H}\right]$ leucine and $\left[{ }^{3} \mathrm{H}\right]$ uridine seemed to be incorporated into protein and RNA. However, the $\left[{ }^{3} \mathrm{H}\right] \mathrm{TdR}$ uptake by $M$. diernhoferi was not affected by 

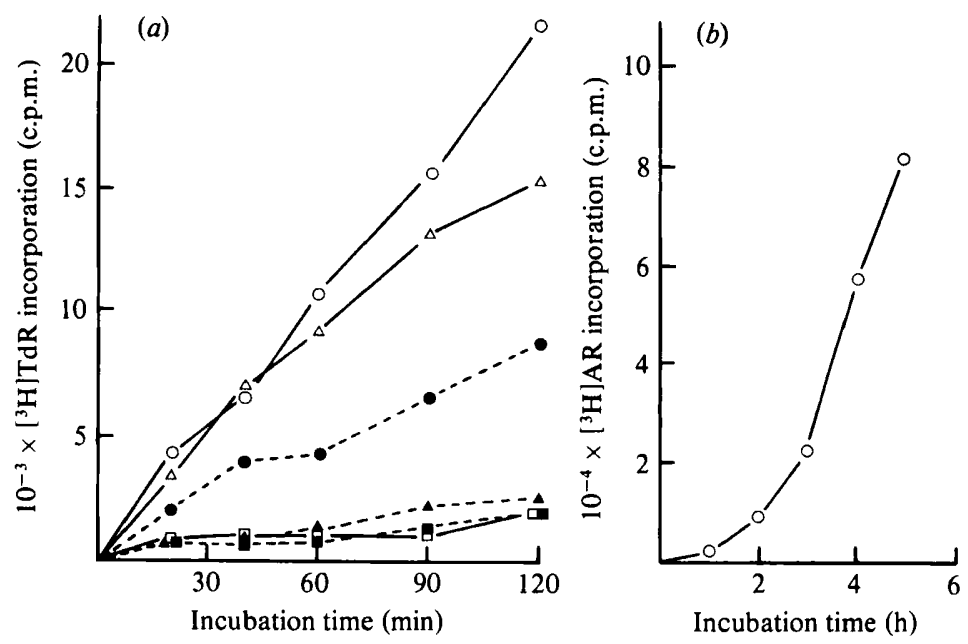

Fig. 1. Incorporation rates of labelled leucine, uridine, adenine and $T d R$ into high molecular weight components (a) and DNA (b) of Mycobacterium diernhoferi ATCC 19340. (a) $\bigcirc,\left[{ }^{3} \mathrm{H}\right]$ Leucine; $O$, $\left[{ }^{3} \mathrm{H}\right]$ leucine + streptomycin $\left(200 \mu \mathrm{g} \mathrm{ml}^{-1}\right) ; \Delta,\left[{ }^{3} \mathrm{H}\right]$ uridine; $\Delta,\left[{ }^{3} \mathrm{H}\right]$ uridine + rifampicin $\left(100 \mu \mathrm{g} \mathrm{ml}^{-1}\right) ; \square,\left[{ }^{3} \mathrm{H}\right] \mathrm{TdR} ; \square,\left[{ }^{3} \mathrm{H}\right] \mathrm{TdR}+$ nalidixic acid $\left(50 \mu \mathrm{g} \mathrm{ml}^{-1}\right) .($ b $)\left[{ }^{3} \mathrm{H}\right]$ Adenine (AR) incorporation into DNA fraction.

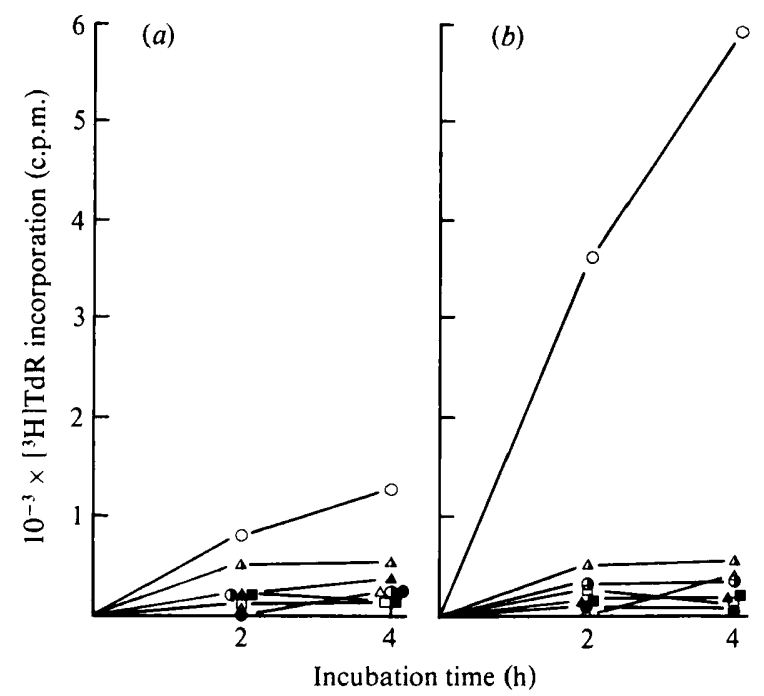

Fig. 2. Incorporation of $\left[{ }^{3} \mathrm{H}\right] \mathrm{TdR}$ into high molecular weight components of $E$. coli $\mathrm{K} 12$ and some rapidly growing mycobacteria in the absence $(a)$ or presence $(b)$ of $100 \mu \mathrm{M}-\mathrm{FUdR}$. $\bigcirc$, E. coli K $12 ; \triangle$, $M$. chelonae A TCC $14472 ; \square, M$. fortuitum ATCC 6841; , M. smegmatis ATCC 14468; $\mathbf{\Delta}, M$. phlei ATCC 19249; $\square, M$. chitae ATCC $19627 ; O, M$. parafortuitum ATCC 19686; $\boldsymbol{\Delta}$, $M$. diernhoferi ATCC 19340

nalidixic acid, indicating that this small $\left[{ }^{3} \mathrm{H}\right] \mathrm{TdR}$ uptake was independent of DNA synthesis. The incorporation of adenine into the DNA fraction of $M$. diernhoferi was comparable with that of leucine and of uridine (Fig. $1 b$ ). Incorporation of $\left[{ }^{3} \mathrm{H}\right] \mathrm{TdR}$ by other rapidly growing mycobacteria such as $M$. fortuitum, $M$. chelonae, $M$. smegmatis, $M$. chitae, $M$. parafortuitum and $M$. phlei was also markedly lower than that of E. coli K12 (Fig. $2 a$ ). When FUdR was added to the culture medium to prevent de novo synthesis of TMP by inhibiting thymidylate synthetase (Mathews \& Cohen, 1963), incorporation of $\left[{ }^{3} \mathrm{H}\right] \mathrm{TdR}$ by $E$. coli was remarkably accelerated, but 
this was not the case for uptake of $\left[{ }^{3} \mathrm{H}\right] \mathrm{TdR}$ by rapidly growing mycobacteria (Fig. $2 b$ ). A separate experiment showed that FUdR at a high concentration $(600 \mu \mathrm{M})$ and a combination of $100 \mu \mathrm{M}$-FUdR with $60 \mathrm{mM}$-AdR failed to augment incorporation of $\left[{ }^{3} \mathrm{H}\right] \mathrm{TdR}$ by $M$. diernhoferi. This indicates a TK deficiency in rapidly growing mycobacteria, because, if a given organism had a substantial amount of TK, the combination of FUdR with AdR should enhance incorporation of TdR into DNA for the following reasons. Firstly, FUdR suppresses de novo TMP synthesis resulting in a recovery of the TK activity from the suppressed state mediated by the de novo TMP synthesis pathway; and secondly, AdR suppresses degradation of TdR by inhibiting TdR phosphorylase (Yagil \& Rosner, 1970).

\section{Lack of TK activity in cell extracts of various mycobacteria}

Since the results described above strongly suggested that rapidly growing mycobacteria lacked TK activity, the cell extracts of various mycobacteria were assayed directly for TK activities. Fourteen strains of the seven species of rapidly growing mycobacteria tested showed no significant TK activity in their cell extracts when they were cultured in Dubos medium (Table 1). Similar TK deficiency was also observed when they were cultivated in heart infusion broth containing glycerol and Tween 80 (data not shown). Table 1 also shows that the cell

\section{Table 1. TK activity of various mycobacteria} Cell extracts of mycobacteria were tested for TK activity at the following protein concentrations in the
reaction mixture: rapid growers, 120 to $200 \mu \mathrm{g} \mathrm{ml}^{-1}$; slow growers, 50 to $110 \mu \mathrm{g} \mathrm{m}^{-1}$.

\section{Strain*}

Rapidly growing mycobacteria

M. fortuitum ATCC $6841^{b}$

M. fortuitum ATCC $23012^{a}$

$M$. chelonae ATCC $14472^{b}$

$M$. chelonae Yamamoto ${ }^{c}$

$M$. smegmatis ATCC $14468^{b}$

M. smegmatis ATCC $19979^{b}$

M. phlei ATCC $19249^{b}$

$M$. phlei WA-289a

$M$. chitae ATCC $19627^{b}$

$M$. chitae ATCC $19629^{b}$

$M$. parafortuitum ATCC $19686^{b}$

$M$. parafortuitum ATCC $19687^{b}$

$M$. diernhoferi ATCC $19340^{\circ}$

$M$. diernhoferi SN1412a

Slowly growing mycobacteria

M. tuberculosis $\mathrm{H} 37 \mathrm{Rv}^{f}$

M. bovis BCGg

M. kansasii ATCC $12478^{a}$

$M$. marinum Kohmoto'

M. gordonae ATCC $14470^{e}$

$M$. scrofulaceum ATCC $15978^{e}$

$M$. intracellulare ATCC $15985^{b}$

$M$. nonchromogenicum ATCC $19530^{e}$

$M$. terrae ATCC $15755^{e}$

$M$. gastri ATCC $15754^{h}$
Relative specific TK activity in cell extract

$$
(\%) \dagger
$$
Relative TK production per $\mathrm{g}$ cell
$(\%) \dagger$

$\begin{array}{ll}0 \cdot 27 & 0 \cdot 03 \\ 0 & 0 \\ 0 & 0 \\ 0 & 0 \\ 1 \cdot 00 & 0 \cdot 03 \\ 0 & 0 \\ 0 & 0 \\ 0 \cdot 09 & 0 \cdot 01 \\ 0 & 0 \\ 0 & 0 \\ 0 & 0 \\ 0 & 0 \\ 0 & 0 \\ 0 & 0\end{array}$

$\begin{array}{ll}1.93 & 0 \cdot 08 \\ 0 & 0 \\ 0 & 0 \\ 0 & 0 \\ 0 & 0 \\ 0 & 0 \\ 0 & 0 \\ 8 \cdot 13 & 0 \cdot 44 \\ 0 & 0 \\ 0 & 0\end{array}$

* Origins of the strains are as follows: $a$, Communicable Disease Center, Atlanta, Ga., USA; $b$, American Type Culture Collection, Rockville, Md., USA; $c$, K. Urabe, Hiroshima University, Hiroshima, Japan; $d$, R. Bonicke, Forschungsinstitut Borstel, Borstel, FRG; e, M. Tsukamura, National Sanatorium, Chubu Hospital, Aichi, Japan; $f$, H. Shoji, Osaka University, Osaka, Japan; $g$, Nihon BCG Seizo Co., Tokyo, Japan; $h$, L. G. Wayne, Veterans Administration Hospital, San Fernando, Calif., USA; $i$, clinical isolate by H. Saito.

$\dagger$ The value for $E$. coli $\mathrm{K} 12$ grown in the same medium as used for these mycobacteria (Dubos medium) was taken as $100 \%$. Specific activity and production of TK in E. coli K 12 were $66 \mathrm{pmol} \mathrm{min}-1 \mathrm{mg}^{-1}$ and 280 units per g cell, respectively. 
extracts from slowly growing mycobacteria grown in Dubos medium lacked TK activity. Separate experiments showed that these mycobacteria grown in Kirchner's medium did not contain any significant amount of TK either (unpublished observation).

\section{Table 2. TK activity of actinomycetes and related organisms}

Cell extracts of the organisms were examined for TK activity at a protein concentration of $200 \mu \mathrm{g} \mathrm{ml}^{-1}$ in the reaction mixture except for Nocardia $\left(500 \mu \mathrm{g} \mathrm{ml}^{-1}\right)$.

\section{Strain*}

Relative specific TK activity in cell extract

Strain*
Nocardia asteroides ATCC 23824
Nocardia asteroides R860
Nocardia asteroides ATCC 19247
Nocardia brasiliensis R432
Nocardia brasiliensis R887
Rhodococcus aurantiacus ATCC 25938
Rhodococcus aurantiacus E7973
Rhodococcus aurantiacus E8182
Streptomyces roseoviridis H646SY3
Streptomyces lavendulae H698SY2
Streptomyces platensis H273SY2
Streptomyces violascens H82NSY7
Corynebacterium cystitidis D454
Corynebacterium pilosum 46HARA
Corynebacterium renale 65 -122

$(\%) \dagger$
0
$0 \cdot 17$
$0 \cdot 56$
$0 \cdot 30$
$0 \cdot 01$
0
0
0
0
0
0
0
$10 \cdot 3$
0
0

* Origins of the strains are as follows: Nocardia and Rhodococcus, M. Tsukamura, National Sanatorium, Chubu Hospital, Aichi, Japan; Streptomyces, S. Nakamura, Hiroshima University, Hiroshima, Japan; Corynebacterium, T. Hiramine, College for Dairy Farming, Hokkaido, Japan.

$\dagger$ The value for $E$. coli $\mathrm{K} 12$ grown in the same media as used for these organisms was taken as $100 \%$. Specific TK activity (pmol $\mathrm{min}^{-1} \mathrm{mg}^{-1}$ ) and TK production (units per $\mathrm{g}$ cell) of $E$. coli $\mathrm{K} 12$ grown in various media were, respectively, as follows: heart infusion broth (for Corynebacterium), $35 \cdot 2$ and 226 ; heart infusion broth containing $4 \%$ glycerol (for Nocardia and Rhodococcus), $34 \cdot 8$ and 174; soluble starch/yeast extract medium (for Streptomyces), $21 \cdot 2$ and 108 .

\section{Table 3. TK activity of bacteria}

Cell extracts of the bacteria were examined for TK activity at a protein concentration of $50 \mu \mathrm{g} \mathrm{ml}^{-1}$ in the reaction mixture, except for $P$. aeruginosa PAO3047, NC-5 and 584A43 $\left(2.5 \mathrm{mg} \mathrm{ml}^{-1}\right)$.

\section{Strain* \\ Relative specific TK activity in cell extract

$$
(\%) \dagger
$$ \\ Relative TK production per $\mathrm{g}$ cell $(\%) \dagger$}

Staphylococcus aureus 209 $\mathrm{P}^{a}$ Streptococcus pyogenes ST $1^{b}$ Bacillus subtilis $\mathbf{B} 7^{b}$

Salmonella typhimurium HKB-1 ${ }^{d}$

Escherichia coli $\mathrm{K} 12^{c}$

Klebsiella pneumoniae Kasuyac

Proteus mirabilis IFO3849

Pseudomonas aeruginosa HKB-2d

Pseudomonas aeruginosa PAO3047e

Pseudomonas aeruginosa NC-5f

Pseudomonas aeruginosa 584A438

29

1130

100

528

34

0

0

$0 \cdot 2$

0 59 4.6 1.8 878 100 329 39

0

0 $0 \cdot 3$

0

* Origins of the strains are as follows: $a$, Y. Kanemasa, Okayama University, Okayama, Japan; $b$, A. Takagi, Tottori University, Tottori, Japan; $c$, A. Matsumae, Kitasato Institute, Tokyo, Japan; $d$, M. Kuwabara, Hiroshima Prefectural Hospital, Hiroshima, Japan; e, M. Kageyama, Mitsubishi Kasei, Institute for Life Science, Tokyo, Japan; $f$, S. Gotoh, Toho University, Tokyo, Japan; $g, \mathrm{~K}$. Okuzumi, Tokyo University, Tokyo, Japan.

$\dagger$ The value for $E$. coli $\mathrm{K} 12$ was taken as $100 \%$. Specific activity and production of TK in $E$. coli K12 were $48.7 \mathrm{pmol} \mathrm{min}-1 \mathrm{mg}^{-1}$ and 147 units per $\mathrm{g}$ cell, respectively. 
Table 4. Effects of cell extracts from various micro-organisms on TK activity of E. coli K12

Cell extracts of the organisms were tested for their effects on TK activity of the cell extract from $E$. coli K 12 under the standard reaction conditions (see Methods). TK activity of $E$. coli $\mathrm{K} 12$ cell extract was measured at a protein concentration of $250 \mu \mathrm{g} \mathrm{ml}^{-1}$ in the reaction mixture with or without the addition of the other cell extracts $\left(250 \mu \mathrm{g}\right.$ protein $\left.\mathrm{ml}^{-1}\right)$.

\section{Cell extract from:}

None
Corynebacterium pilosum 46HARA
Streptomyces violascens H82NSY7
Nocardia asteroides ATCC 23824
Nocardia brasiliensis R432
Rhodococcus aurantiacus ATCC 25938
Mycobacterium intracellulare ATCC 15985
Mycobacterium kansasii ATCC 12478
Mycobacterium chelonae Yamamoto
Mycobacterium fortuitum ATCC 6841
Mycobacterium smegmatis ATCC 14468
Mycobacterium phlei ATCC 19249

$\begin{array}{cc}\begin{array}{c}\text { TMP } \\ \text { generation } \\ \left(\text { nmol } \text { min }^{-1}\right)^{*}\end{array} & \begin{array}{c}\text { Inhibition } \\ (\%)\end{array} \\ 575 & 0 \\ 389 & 32 \\ 147 & 74 \\ 471 & 18 \\ 490 & 15 \\ 432 & 25 \\ 537 & 7 \\ 315 & 45 \\ 469 & 18 \\ 137 & 76 \\ 456 & 21 \\ 412 & 28\end{array}$

* The amount of TMP generation in the reaction mixture $(0 \cdot 2 \mathrm{ml})$.

\section{$T K$ deficiency in mycobacteria-related organisms}

Table 2 shows TK activity of the cell extracts of the strains of Corynebacterium, Streptomyces, Nocardia and 'Gordona'. All the organisms tested were essentially free from TK activity, except C. cystitidis which contained a low but significant amount of TK. Thus, the TK deficiency seemed to be a common feature of actinomycetes and related organisms. Table 3 shows the distribution of TK among common Gram-positive and Gram-negative bacteria. The Grampositive cocci and rods, such as Staphylococcus aureus, Streptococcus pyogenes and B. subtilis had a comparable but lower amount of cell-associated TK than did E. coli K12. Enterobacteriaceae had a markedly high TK activity: Salmonella typhimurium and Klebsiella pneumoniae had 5- to 11-fold high TK activity than E. coli K 12. The TK activity of Proteus mirabilis was somewhat lower than that of $E$. coli K12. As in the case of Pseudomonas schuylkilliensis (Mizuno, 1969), $P$. aeruginosa lacked TK activity.

Effects of cell extracts of some actinomycetes and related organisms on TK activity of E. coli K12

Representative cell extracts of actinomycetes and related organisms lacking TK activity were examined for their effects on the TK activity of the cell extract of E. coli K12 under the standard reaction conditions. Most cell extracts had a weak inhibitory activity against the enzyme action by TK of E. coli K12 (6 to $32 \%$ inhibition; Table 4), whereas the extracts of Streptomyces violascens, Mycobacterium kansasii and $M$. fortuitum showed a somewhat greater inhibition.

\section{DISCUSSION}

We examined TK activity in cell extracts of various organisms. In most of the actinomycetes and related organisms studied TK activity was undetectable by our assay system. This does not appear to be due to the different physiological state of test organisms from that of $E$. coli $\mathrm{K} 12$, for the following reasons. Firstly, the TK activity of a given organism was comparable to that of $E$. coli $\mathrm{K} 12$ grown in the same medium and secondly, Corynebacterium pilosum, C. renale, Nocardia asteroides, $N$. brasiliensis, Rhodococcus aurantiacus and various rapidly growing mycobacteria lacked cell-associated TK activity, although the cultivation time for them was the same as that for $E$. coli $\mathrm{K} 12(2 \mathrm{~d})$. These examples suggest that the apparent TK deficiency in actinomycetes and related organisms is not due to a prolonged cultivation which may cause an increase in the ratio of physiologically inactive cells. Thus, it seems that actinomycetes and related organisms have an inherent TK deficiency. It was also found that Pseudomonas aeruginosa $(24 \mathrm{~h}$ 
cultivation) lacked cell-associated TK activity. Preliminary experiments showed that all the cultured cells of $P$. aeruginosa harvested at $6,12,24,48$ or $72 \mathrm{~h}$ had little, if any, TK activity (unpublished observation). Thus $P$. aeruginosa seems to lack the ability to produce TK.

When representative cell extracts of actinomycetes and related organisms were tested for their effects on TK activity of cell extract from $E$. coli $\mathrm{K} 12$, many were only weakly inhibitory although others showed definite inhibition ( 45 to $76 \%$ : Table 4$)$. The inhibitory factor in the cell extracts of these microbes may be an active inhibitor directed against TK itself (Okazaki \& Kornberg, 1964b; Kizer \& Holman, 1974; Madhav et al., 1980), TMP phosphatase, or TdRdecomposing enzymes such as TdR phosphorylase. The inhibitor may be an ATP phosphatase which stimulates $T d R$ degradation in the reaction mixture by lowering the concentration of ATP (this antagonizes TdR degradation) as reported by Grivell \& Jackson (1968). In any case, the inhibitory activity in the cell extracts of these organisms is too low to cause a complete lack of TK activity. Since the cell extracts were stored at -20 or $-80^{\circ} \mathrm{C}$ until use and the reaction mixture contained a sufficient amount of bovine serum albumin as TK stabilizer (Okazaki \& Kornberg, 1964a; Kizer \& Holman, 1974), the possibility can be excluded that the TK of these organisms was inactivated during their storage or enzyme assay incubation, although TK of $E$. coli and mammalian origin is unstable (Okazaki \& Kornberg, 1964a; Hopgood \& Ballard, 1974; Kizer \& Holman, 1974; Ellims \& Van Der Weyden, 1980).

The present findings strongly suggest an inherent deficiency of TK in the actinomycetes (Nocardia and Streptomyces) and related organisms (Mycobacterium, Rhodococcus and Corynebacterium). Preliminary experiments have also shown a similar TK deficiency in Propionibacterium and Bifidobacterium (unpublished observations). It has been reported that Neurospora crassa, Saccharomyces cerevisiae, Aspergillus nidulans and Euglena gracilis (Grivell \& Jackson, 1968) and Chlamydia psittaci (Hatch, 1976) also lack TK. Our preliminary experiments have shown that Candida and Cryptococcus also lack TK (unpublished observations). Thus, it seems that TK deficiency is a general property of actinomycetes, fungi and related micro-organisms. Since TK is a key enzyme in the salvage pathway for TMP synthesis, the TK deficiency indicates that these organisms cannot use extracellular TdR, which is generated by DNA decomposition due to the action of extracellular deoxyribonuclease, to supply TTP for their DNA synthesis. It is of interest to know what kind of advantage and/or disadvantage is given to these taxonomically related micro-organisms by being deprived of their TK-producing ability. It is also of interest to know why Pseudomonas aeruginosa acquired the phenotype (genotype) of TK deficiency in its evolution, for the following reasons. This microbe grows rapidly in comparison to other bacteria. It is disadvantageous for such a rapidly growing organism to lack an inherent TK, since the salvage pathway for TMP (finally TTP) synthesis catalysed by TK has much higher activity than that of the de novo pathway, particularly in supplying TTP for active DNA synthesis (Hotta \& Stern, 1963; Okazaki \& Kornberg, 1964a, b). A study to elucidate the precise meaning of the TK deficiency in these organisms is now under way.

We thank the following investigators for providing cultures: $M$. Tsukamura, National Sanatorium, Chubu Hospital, Aichi; S. Nakamura, Hiroshima University, Hiroshima; T. Hiramine, College for Dairy Farming, Hokkaido, Japan. We also thank $M$. Ohara for reading this manuscript.

\section{REFERENCES}

Ellims, P. H. \& Van Der Weyden, M. B. (1980). Human liver thymidine kinase. Purification and some properties of the enzyme. Journal of Biological Chemistry 255, 11290-11295.

Ellims, P. H. \& VAN Der Weyden, M. B. (1981). Kinetic mechanism and inhibition of human liver thymidine kinase. Biochimica et biophysica acta 660 , 238-242.

Goodfellow, M. (1971). Numerical taxonomy of some nocardioform bacteria. Journal of General Microbiology 69, 33-80.

Grivell, A. R. \& JaCkson, J. F. (1968). Thymidine kinase: evidence for its absence from Neurospora crass $a$ and some other micro-organisms, and the relevance of this to the specific labelling of deoxyribonucleic acid. Journal of General Microbiology 54, 307-317.

Guirard, B. M. \& Snell, E. E. (1981). Biochemical factors in growth. In Manual of Methods For General Bacteriology, pp. 79-111. Edited by P. Gerhardt, R. G. E. Murray, R. N. Costilow, E. W. Nester, W. A. Wood, N. R. Krieg \& G. B. Phillips. Washington: American Society for Microbiology. HATCH, T. P. (1976). Utilization of exogenous thymi- 
dine by Chlamydia psittaci growing in thymidine kinase-containing and thymidine kinase-deficient $\mathrm{L}$ cells. Journal of Bacteriology 125, 706-712.

HotTA, Y. \& STERN, H. (1963). Molecular factors of mitotic regulation, I. Synthesis of thymidine kinase. Proceedings of the National Academy of Sciences of the United States of America 49, 648-654.

HOPGOOD, M. F. \& BALLARD, F. J. (1974). The relative stability of liver cytosol enzymes incubated in vitro. Biochemical Journal 144, 371-376.

Kizer, D. E. \& Holman, L. (1974). Purification and properties of thymidine kinase from generating rat liver. Biochimica et biophysica acta 350, 193-200.

LiU, C., Hermann, T. \& Miller, P. A. (1977). Feedback inhibition of the synthesis of an antibiotic: Aurodox (X-5108). Journal of Antibiotics 30, 244-251.

Madhav, R., Coetzee, M. L. \& Ove, P. (1980). Purification of thymidine kinase by affinity chromatography with an enzyme inhibitor as the ligand. Archives of Biochemistry and Biophysics 200, 99-107.

Mathews, C. K. \& Cohen, S. S. (1963). Inhibition of phage-induced thymidylate synthetase by 5 -fluorodeoxyuridylate. Journal of Biological Chemistry 238, 367-370.

Michrina, C. A. \& DeEring, R. A. (1980). Thymidine kinase activity in Dictyostelium discoideum. Journal of General Microbiology 119, 263-266.

Mizuno, S. (1969). Fractionation of nucleic acids. In Methodology for Biochemistry: [A-2] Separation,
Purification, and Measurement of Nucleic Acids, pp. 16-67. Edited by I. Uritani, H. Shimura, M. Nakamura \& M. Funazu. Tokyo: Tokyo University Press.

OkAZAKI, R. \& Kornberg, A. (1964a). Deoxythymidine kinase of Escherichia coli. I. Purification and some properties of the enzyme. Journal of Biological Chemistry 239, 269-274.

OkaZAKI, R. \& KornberG, A. (1964b). Deoxythymidine kinase of Escherichia coli II. Kinetics and feedback control. Journal of Biological Chemistry 239, 275-284.

Stock, D. A. \& Gentry, G. A. (1971). Thymidine metabolism in Mycoplasma hominis. Journal of General Microbiology 65, 105-107.

Takeya, K., Shimamoto, M. \& Mizuguchi, Y. (1978). Physicochemical and biological properties of mycobacteriocin M12 produced by Mycobacterium smegmatis ATCC 25855. Journal of General Microbiology 109, 215-223.

Wachsman, J. T. \& Morgan, D. D. (1971). Deoxyribonucleoside kinases of Bacillus megaterium $\mathrm{KM}$. Journal of Bacteriology 105, 787-792.

WAyne, L. G., DoubeK, J. R. \& Russell, R. L. (1964). Classification and identification of mycobacteria $I$. Tests employing Tween 80 as substrate. American Review of Respiratory Disease 90, 588-597.

YAGIL, E. \& RosNer, A. (1970). Effect of adenosine and deoxyadenosine on the incorporation and breakdown of thymidine in Escherichia coli K-12. Journal of Bacteriology 103, 417-421. 